\title{
Male Reproductive Complications of Diabetes Mellitus and Possible Medicinal Plant Remedies: A Review.
}

\author{
Arokoyo D.S. ${ }^{1}$, *Oyeyipo I.P. ${ }^{2}$, Du Plessis S.S. ${ }^{2}$, Aboua Y.G. ${ }^{1}$
}

\begin{abstract}
Objective: Male reproductive dysfunction and subsequent infertility are major complications that are becoming increasingly associated with Diabetes Mellitus (DM). Due to frequent failure in treatment with orthodox antidiabetic drugs, there has been a massive shift of attention to alternative therapies. The antidiabetic potential of a large number of medicinal plants have been investigated both in-vitro and in experimental animal models. These specific plants were predominantly used because of the antioxidant capacity of their bioactive phytoconstituents. This review focuses on reproductive dysfunctions commonly suffered by male diabetic patients and medicinal plants that have been tested and reported for their roles in ameliorating such dysfunctions.
\end{abstract}

Method: All original journal articles and reviews cited on PubMed between 2005 and 2015 in English language were considered for this review.

Results and conclusion: This review reestablished the fact that male infertility is a common complication of poorly managed diabetes mellitus. It also highlighted the fact that the numerous challenges associated with the use of orthodox drugs in management of the disease makes medicinal plant therapy inevitable. However, the full potentials of these medicinal plants at correcting reproductive complications of the disease are still to be realized and more specific studies are required in this field for improved therapeutic outcomes.

Keywords: Diabetes, Complications, Medicinal Plants, Erectile dysfunction, Remedies.

*Corresponding author: Oyeyipo I.P.; E-Mail: greatibuks@yahoo.com

${ }^{1}$ Department of Biomedical Sciences, Faculty of Health and Wellness Sciences, Cape Peninsula University of Technology, Bellville, Cape Town, South Africa.

${ }^{2}$ Division of Medical Physiology, Faculty of Medicine and Health Sciences, Stellenbosch University, Tygerberg, South Africa.

Research Journal of Health Sciences subscribed to terms and conditions of Open Access publication. Articles are distributed under the terms of Creative Commons Licence (CC BY-NC-ND 4.0). (http://creativecommons.org/licences/by-nc-nd/4.0).

http://dx.doi.org/10.4314/rejhs.v5i3.2 


\title{
Les complications reproductives chez l'homme du diabète sucré et des remèdes possibles pour les plantes médicinales: un examen.
}

\author{
Arokoyo D.S. ${ }^{1}$, *Oyeyipo I.P. ${ }^{2}$, Du Plessis S.S. ${ }^{2}$, Aboua Y.G. ${ }^{1}$ \\ Resume \\ Objectif: Le dysfonctionnement reproducteur masculin et l'infertilité subséquente sont des complications \\ majeures qui sont de plus en plus associées au diabète sucré (DM). En raison de l'échec fréquent dans le \\ traitement avec les médicaments antidiabétiques orthodoxes, il y a eu un changement massif d'attention \\ aux thérapies alternatives. Le potentiel antidiabétique d'un grand nombre de plantes médicinales a été \\ étudié à la fois in vitro et dans des modèles animaux expérimentaux. Ces plantes spécifiques ont été \\ principalement utilisées en raison de la capacité antioxydante de leurs phytoconstituants bioactifs. Cette \\ revue se concentre sur les dysfonctionnements reproductifs couramment subis par les patients diabétiques \\ mâles et les plantes médicinales qui ont été testés et rapportés pour leurs rôles dans l'amélioration de ces \\ dysfonctionnements.
}

Méthode: Tous les articles de revues originales et les critiques cités sur PubMed entre 2005 et 2015 en langue anglaise ont été considérés pour cette revue.

Résultats et conclusion: Cette revue a rétabli le fait que l'infertilité masculine est une complication fréquente du diabète sucré mal géré. Il a également souligné le fait que les nombreux défis associés à l'utilisation de médicaments orthodoxes dans la prise en charge de la maladie rendent inévitable la thérapie par les plantes médicinales. Cependant, les pleins potentiels de ces plantes médicinales pour corriger les complications reproductives de la maladie doivent encore être réalisés et des études plus spécifiques sont nécessaires dans ce domaine pour améliorer les résultats thérapeutiques.

Mots-clés: Diabète, Complications, Plantes médicinales, Dysfonction érectile, Remèdes.

*Auteur correspondant: Oyeyipo I.P.; E-Mail: greatibuks@yahoo.com

${ }^{1}$ Department of Biomedical Sciences, Faculty of Health and Wellness Sciences, Cape Peninsula University of Technology, Bellville, Cape Town, South Africa.

${ }^{2}$ Division of Medical Physiology, Faculty of Medicine and Health Sciences, Stellenbosch University, Tygerberg, South Africa.

Research Journal of Health Sciences subscribed to terms and conditions of Open Access publication. Articles are distributed under the terms of Creative Commons Licence (CC BY-NC-ND 4.0). (http://creativecommons.org/licences/by-nc-nd/4.0).

http://dx.doi.org/10.4314/rejhs.v5i3.2 


\section{INTRODUCTION}

In 2012, the American Diabetes Association defined Diabetes Mellitus (DM) as a group of metabolic diseases characterized by hyperglycaemia and resulting from defects in insulin secretion, insulin action, or both (1). Two major etiopathogenetic classes of DM namely, type 1 or Insulin Dependent DM (IDDM) and type 2 or Non-Insulin Dependent DM (NIDDM) are widely recognized (1). Insulin Dependent Diabetic Mellitus is caused by absolute insulin deficiency due to autoimmune destruction of the pancreatic $\beta$-islet cells, while NIDDM is usually as a result of a combination of insulin resistance and inadequate compensatory insulin release response (1). The main feature of DM is chronic hyperglycaemia which results in long-term damage, dysfunction, and failure of different organs, involving virtually all systems of the body. Diabetes is a major public health challenge, increasingly affecting millions of people across all age groups worldwide (2). If not well managed, it results in a wide range of complications including neuropathy, retinopathy, cardiovascular diseases, renal diseases and reproductive dysfunction (2).

A large number of studies, both in diabetic humans and animal models associated DM with impotence, erectile dysfunction, retrograde ejaculation and hypogonadism (2). Despite this, the disease was not directly linked with male infertility until recently when findings revealed that diabetes induces subtle molecular alterations which are very paramount to spermatogenesis and sperm physiology (3). The role of DM in the incidence of male infertility is poorly reported and available data is characterized with controversies and inconsistencies (4). However, due to the conflicting reports on the influence of diabetes on the endocrine control of spermatogenesis, it was concluded that, DM may affect male reproductive function at multiple levels and the individual anomalies may not have any significant effect on reproductive function (5).

There has been a major upsurge in the number of research publications on DM in the last decade with special attention towards finding alternative plant remedies for the troublesome disease. Often, the attention is fixed on the ability of these plant agents to restore glycaemic control and reverse hyperglycaemia with little recourse to the correction of the disease complications. This review focuses on the reported male reproductive complications of DM and the medicinal plant materials that have been investigated for their efficacies in correcting such complications.

\section{MATERIALS AND METHODS}

This review considered all original journal papers and reviews cited on PubMed from 2005 to 2015. Few selected, exceptionally relevant publications outside this period were also reviewed. Only the studies published in English language were considered and keywords such as; 'Diabetes mellitus, definition and complications, medicinal plant treatment, diabetes mellitus and male reproductive dysfunction' were used for the search.

\section{Male Reproductive dysfunctions in diabetes mellitus}

Diabetes mellitus is not routinely investigated in cases of male infertility due to the scanty and conflicting research findings on the subject matter, but this may start to change in the wake of recent reports. La Vignera et al. (4) reported $1.2 \%$ prevalence of DM in the male counterparts of couples that were treated for infertility, $35.1 \%$ infertility cases among men with type $2 \mathrm{DM}$, and $51 \%$ subfertility among DM patients in general. These reported cases of infertility might be attributable to the following reported male reproductive complications of DM.

Morphologic effects: DM causes a significant reduction in testicular weight and total number of Leydig cells in the testes $(6,8)$. This may be linked with the reported low testosterone levels and histological changes induced by DM in the testes (6). Hyperglycaemia was also recently reported to induce apoptotic damage and cause morphologic impairment in the testes (8). This could further explain the testicular changes observed in diabetic subjects (see Fig. 1 [ii] \& [v]). Histologically, a regression in the absolute weight of the caput, corpus and caudal regions of the epididymis, accompanied with reduction in tubule and lumen size, as well as increased interstitial stroma has been observed in the testes of Streptozotocin (STZ)-induced diabetic Wistar rats (9).

Effects on spermatogenesis and sperm parameters: Several studies conducted in both diabetic humans and animal models revealed that DM may have a deleterious effect on the process of spermatogenesis as suggested by reports of 
subnormal sperm parameters $(3,4,10)$. Testosterone, the major hormone that drives spermatogenesis, has been found to be decreased in diabetic men due to impaired Leydig cell function (11). There are contradictory and inconsistent reports with regards to the exact impact DM has on semen quality (3). For instance, Delfino et al. (12) reported that there was no difference in sperm concentration of semen samples from diabetic men when compared to non-diabetic controls, whereas, Amaral et al. (11) reported a deterioration of all sperm parameters including sperm density in diabetic men. In a separate study on diabetic and non-diabetic human semen, Agbaje et al. (5) found a positive association between DM and sperm nuclear and mitochondrial DNA damage, in spite of zero effect on the conventional semen parameters (see Fig. 1 [iii]). The controversy deepened recently when a study, designed to evaluate the isolated effect of high glucose concentration on human semen reported that 'high glucose levels per se have no adverse effect on sperm function in vitro' (13). However, it can be deduced from the overwhelming majority of literature reports that spermatogenesis and consequently, at least one or more of the parameters determining semen quality and fertility (namely: sperm count, sperm concentration, motility, kinetics, morphology, semen fructose/glucose level, semen $\mathrm{pH}$ and semen volume) are adversely affected by DM (4, $5,11,14)$.

Effects on sexual behaviour: The processes controlling male libido, penile erection and ejaculation are largely autonomic, and DM is known to be complicated by autonomic neuropathy (2). One of the most reported reproductive complications of DM in men is Erectile Dysfunction (ED) (15). It simply means the inability to achieve and/or sustain penile erection long enough for adequate sexual relations (11). The prevalence of ED among diabetic men ranges from $20 \%$ to $85 \%$ and the etiology can be from either one or a combination of any of vascular, neurological and endocrine anomalies (15). Moore and Wang (16) reported that ED affects $32 \%$ of IDDM and $46 \%$ NIDDM patients and is found to be the presenting complaint in about $12 \%$ of all diabetic patients (16). Another report, however, places the prevalence of ED in NIDDM at $75 \%$ (17), thus, emphasizing the variability of occurrence in different populations of diabetic patients. The pathophysiology of ED in diabetic patients is multifactorial and includes: end organ damage by Advanced Glycation End-products (AGEs), increased oxygen free radicals, decreased smooth muscle in the corpus cavernosum due to increased apoptosis, impaired nitric oxide synthesis, nitric oxide-cyclic guanosine monophosphate (NO-cGMP) pathway dysfunction and effects of comorbid conditions, among others $(16,18,19)$ (see Fig. 1 [iv]). All these causes of ED were recently reported to culminate in up-regulation of the Transforming Growth Factor $\beta 1 / \mathrm{Smad}$ (TGF- $\beta 1 / \mathrm{Smad}$ ) signaling pathway which is a final common pathway of tissue insult (20).

Ejaculatory dysfunction secondary to autonomic neuropathy syndrome and depletion in serum testosterone level is another common sequela of DM (21). This dysfunction actually describes a range of anomalies from premature ejaculation to total failure of ejaculation (such as anejaculation or retrograde ejaculation), and DM is a common cause (22). Pontes and colleagues (21) conducted an extensive study on the role of testosterone supplementation in diabetic male Wistar rats that exhibited reduced sexual activity and failure of ejaculation. They reported only $33.3 \%$ sexual activity and ejaculation in diabetic rats as compared to $89.0 \%$ in the control group. Ejaculatory behaviour improved to about $62.5 \%$ after three weeks of testosterone supplementation, confirming their conclusion that DM induces ejaculatory dysfunction by causing low serum testosterone levels (21).

Other disturbances in sexual function common in DM which are probably neurologic and psychological in etiology include: reduced libido and Retrograde Ejaculation (RE) (11). In $\mathrm{RE}$, the semen is released into the male urinary bladder rather than the female genital tract during sexual intercourse. This is due to bladder neck dysfunction from DM-induced autonomic neuropathy (21).

Endocrinological effects: The role of abnormal hormone regulation in diabetic induced male reproductive dysfunction is multifaceted. Diabetic neuropathy can affect the hypothalamus or anterior pituitary leading to secondary testicular failure exhibited by low serum levels of gonadotropins and testosterone (23). A direct effect on the Leydig cells will usually result in primary testicular failure which in contrast to secondary failure, presents with low serum testosterone and high gonadotropin level (24) 
(see Fig. 1 [i] \& [ii]). The direct effect of insulin interaction with the testes and spermatozoa has also been suggested as a possible basis for the reproductive complications of DM, since both testes and spermatozoa themselves produce insulin (24). The possibility of insulin playing an important role in spermatogenesis was reemphasized by the report that the process was impaired in both diabetic men and knockout mice (2). However, it is not clear if this effect is induced via testicular insulin insufficiency or through the systemic effects of DM.

A study recently described an association between diabetic-induced functional hypercortisolism and hypogonadism. The researchers conducted a retrospective clinical comparative study between fifteen diabetic patients with hypercortisolism and late onset hypogonadism and another group of fifteen nonhypercortisolic diabetic patients also with late onset hypogonadism. All sexual parameters were found to be significantly worse in the hypercortisolic group and it was suggested that 'the dysregulated hypothalamic-pituitary-adrenal axis has an impairing influence on sexual function in diabetes mellitus-associated lateonset hypogonadism' (25).

\section{Medicinal plants in the treatment of diabetes- induced male reproductive dysfunction}

The management of DM as a disease entity is very elaborate and multidisciplinary in approach. Insulin therapy and/or use of oral antihyperglycaemic agents have been central in the disease management. However, the numerous challenges of these drugs, ranging from cost, dosing, administration techniques, to side effects among others, have necessitated a wanton shift of research attention to alternative therapy in medicinal plants.

Many medicinal plants have been used empirically in the treatment of male infertility from diverse etiologies (26), but only a few have been investigated for their specific roles in correcting or ameliorating reproductive dysfunctions secondary to DM.

\section{Animal studies}

Effects on the morphology of reproductive organs: Methanol extract of Amaranthus spinosus (spiny pigweed) stem was found to increase testicular weight significantly in STZinduced diabetic rats after fifteen days of oral administration (27). Extracts of Dracaena arborea (Tree Dracaena) root barks also partially corrected diabetes-induced morphological impairment of the testes and led to increased testicular weight in experimental rats even without having any significant effect on blood glucose after three weeks of oral treatment (7). This effect of $D$. arborea was attributed to the antioxidant and androgenic properties of saponins, phenols, flavonoids and phytosterols found in both aqueous and ethanol extracts of the plant's root (7). Allium sativum (Garlic) has similar positive effect on testicular weight and number of Leydig cells in diabetic rats and also ameliorated reproductive complications of STZinduced diabetes in pretreated rats (6). The ethyl acetate fraction of Eugenia jambolana (Jambul tree) seed, when given orally for sixty days to experimental diabetic rats resulted in a significant recovery in weights of testes and all accessory reproductive organs (28). Mallick et al. (29) investigated the effectiveness of a herbal mixture, MTEC, comprising of root of Musa paradisiaca (Banana), seeds of Tamarindus indica (Indian date) and Eugenia jambolana (Jambul) and leave of Coccinia indica (Baby watermelon) in ratio $2: 2: 1: 1$, in correcting reproductive dysfunction in male diabetic rats. MTEC was reported to improve all testiculosomatic indices that were earlier deteriorated by STZ injection. Quercetin, which is a flavonoid that is also found abundantly in onions, prevented all histological abnormalities that are usually associated with DM in STZ treated Wistar rats (30). Additionally, Long et al (8) evaluated the effect of pharmaceutical product, scutellarin, an active component of Erigeron breviscapus (fleabane) in type 2 diabetes rat models. Scutellarin was found to significantly inhibit the formation of apoptotic cells and morphological damage in the testes caused by $\mathrm{DM}(8)$.

Effects on spermatogenesis and sperm parameters: Amaranthus spinosus, Eugenia jambolana and MTEC increased sperm count significantly in diabetic rats $(27,28,29)$. Quercetin reportedly restored epididymal sperm count, sperm motility and sperm viability in STZinduced diabetic rats (30). While both methanol and aqueous extracts of Zingiber officinale (Ginger) root were found to significantly enhance sperm parameters and sexual indices (31).

Effects on erectile function: Icariside II (ICA II), an active component of herba epimedii (horny goat weed) was investigated and found to improve erectile function in STZ-induced diabetic rats with ED. ICA II achieved this by 
increasing the neuronal and endothelial Nitric Oxide Synthase (nNOS and eNOS) as well as the Vascular Endothelial Growth Factor (VEGF) in penile tissues. It also down-regulated the TGF$\beta 1 /$ Smad2 pathway and decreased apoptotic index in the corpus cavernosum of diabetic rat after twelve weeks of oral treatment (32). S-Allyl Cysteine (SAC), a bioactive component of garlic significantly improved erectile function in diabetic rats after four weeks of treatment, owing to its ability to reduce formation of Reactive Oxygen Species (ROS) in penile tissue (33). Furthermore, caffeine had similar effect after eight weeks of treatment, acting via a different mechanism (34). Likewise, Cyanidin-3-O- $\beta$-Dglucopyranoside $(\mathrm{C} 3 \mathrm{G})$; concentrated materials from mulberry fruit was reported to protect and improve erectile function in STZ-induced diabetic male Sprague-Dawley rats (35).

Hormonal effects: Both serum and testicular testosterone levels in diabetic rats were significantly increased after fifteen days of oral administration of Amaranthus spinosus stem and sixty days of oral treatment with ethyl acetate extract of Eugenia jambolana seed $(27,28)$. Cinnamomum zeylanicum (Cinnamon) and Zingiber officinale, when administered individually or combined increased serum testosterone, luteinizing hormone and follicle stimulating hormone, as well as enhanced spermatogenesis in STZ-induced diabetic rats $(31,36)$. The use of both plants appears to produce synergistic effect since these hormonal effects were greater with combined administration. MTEC and Quercetin are other substances reported to increase serum testosterone and enhance testicular antioxidative capacity in diabetic rats $(29,30)$. Curculigo orchioides (black musli) is one of the few medicinal plants whose Rhizome extract was specifically reported for their role in enhancing libido in experimental diabetic animals (37). The exact mechanism underlying this effect was not ascertained, however, modulation of the actions and blood levels of reproductive hormones may play a part.

\section{Human studies}

In contrast to the array of reports on scientific studies investigating the efficacy of numerous medicinal plants in the treatment of reproductive dysfunctions in experimentally induced DM in animals, only a very few human studies are available in this respect.
Many plants have been used empirically in the traditional settings to alleviate various reproductive dysfunctions especially poor libido, sexual asthenia and erectile dysfunction (26), but these have not been specifically investigated in diabetic patients. Curculigo orchioides is a herb known for its potent antioxidant and adaptogenic properties and used in ayurvedic medicine as a sexual tonic in diabetic men (37). This has been confirmed in diabetic animal models (37), but no report of any scientific study in diabetic humans is available.

A summary of some studies involving medicinal plants that have been reported for their efficacies in treating reproductive complications of DM is presented in table 1 .

\section{DISCUSSION}

This review clearly re-emphasizes the possibility of occurrence of male infertility as a complication of DM especially when poorly managed. It may further justify the recent equitable distribution of the etiology of infertility between both sexes, rather than the usual stigmatization of the female partner alone (26), since DM is not gender biased. As mentioned earlier, the complications of DM cuts across most systems of the body, but the reproductive effects are topical owing to the sensitive nature and cultural implications of infertility in many societies (38).

From many of the studies reviewed, it is obvious that the increased generation of oxidative stress is central in the pathophysiology of most of the reproductive dysfunctions seen in $\operatorname{DM}(2,3,16,19)$ (see Fig.1). Oxidative stress has been linked directly or indirectly to the sustained hyperglycaemia characteristic of the disease and therefore a large number of plants investigated for antidiabetic properties were so used because of their antioxidant or antihyperglycaemic potential $(6-8,28,30)$.

It is noteworthy, that a very large number of medicinal plants have been reported to be useful in the treatment of male reproductive dysfunctions and infertility (26). However, only a few of these have been investigated for their efficacy in the treatment of male reproductive dysfunctions secondary to DM. Likewise, a large fraction of medicinal plants known for their antidiabetic potentials has not been specifically investigated for the correction of the reproductive complications of DM. These aspects of diabetic research cannot be discarded especially when some plants like Dracaena arborea were found to 
improve sexual function in diabetic rats without any significant effect on blood glucose (7). This implies that the correction of diabetic complications is not always dependent on antihyperglyceamic effect of a substance.

The present review also revealed a striking paucity of information with regards to the exact efficacy of medical plants in the treatment of DM-induced reproductive dysfunction in men, since there were no human studies published within the scope of our review. Virtually all investigations in this field during the time frame of this study were carried out on animal models while a large number of these medicinal plants continued to be used empirically in various traditional settings without proper therapeutic trial. The need to change this cannot be overemphasized.

Erectile dysfunction is one of the most common reproductive dysfunctions in male diabetics and yet poorly investigated. Report from one study indicated a difference in response to therapy when comparing patients of DMinduced ED to other patients of ED in the general population, with the diabetic patients showing poorer response $(39,40)$. Despite these reports, there was no single human study published within the period captured under this review that considered the effectiveness of medicinal plants in the treatment of DM-induced ED. There is therefore the need to specifically investigate many more of these medicinal plants and carry out an in-depth analysis of their therapeutic efficacies in the management of specific reproductive dysfunctions caused by DM in both animal models and human diabetic subjects. This will go a long way in instituting standard alternative therapies and improving the living conditions of many diabetic patients.

\section{CONCLUSION}

The use of medicinal plants in the general management of DM has offered a renewed hope of better therapeutic outcome but this however has not yielded any noticeable reduction in the prevalence of systemic complications, including reproductive dysfunctions in diabetic patients. This study highlighted the paucity of information with regards to the potentials of medicinal plants in correcting male reproductive dysfunctions caused by DM. It was therefore concluded from the review that, the use of medicinal plants in the management of DM-induced male reproductive dysfunction in humans is still largely empirical.
Further scientific studies, as well as clinical therapeutic trials in human subjects are required to completely evaluate the role of these natural substances.

Conflict of interest: The authors declare no conflict of interest.

Acknowledgement: The authors acknowledge Bowen University (of Baptist Convention), Iwo, Nigeria, for the time allowed to conduct this study.

\section{REFERENCES}

1. American Diabetic Association. Diabetes care 2012; 35(1): s64-s75.

2. Jain GC, Jangir RN. Modulation of diabetesmellitus-induced male reproductive dysfunctions in experimental animal models with medicinal plants. Pharmacogn Rev. 2014; 8(16): 113-121.

3. Mallidis C, Agbaje I, McClure N, Kliesch S. The influence of diabetes mellitus on male reproductive function: A poorly investigated aspect of male infertility. Urologe. 2011; 50(1): 33-7.

4. La Vignera S, Condorelli R, Vicari E, D'agata R, Calogero AE. Diabetes mellitus and sperm parameters. J. Androl. 2012; 33 (2): 145-153.

5. Agbaje IM, Rogers DA, McClure CM, Atkinson AB, Mallidis C, Lewis SEM . Insulin dependent diabetes mellitus: Implications for male reproductive function. Hum Reprod. 2007; 22(7): 1871-1877.

6. Abdolahnejad A, Gol A, Dabiri S. Garlic effects on reproductive complications of diabetes mellitus in male rats. Physiol Pharmacol. 2009; 13(3): 297-307.

7. Wankeu-Nya M, Florea A, Balici S, Watcho P, Matei H, Kamanyi A. Dracaena arborea alleviates ultra-structural spermatogenic alterations in streptozotocin-induced diabetic rats. BMC Complement Altern Med. 2013; $13: 71$.

8. Long L, Wang J, Lu X, Xu Y, Zheng S, Luo C. Protective Effects of Scutellarin on Type II Diabetes Mellitus-Induced Testicular Damages Related to Reactive Oxygen Species/Bcl-2/Bax a $\mathrm{n} \mathrm{d} \quad \mathrm{R}$ e a c t i v e O x y g e $n$ Species/Microcirculation/Staving Pathway in Diabetic Rat. J Diabetes Res. 2015; Volume 2015, Article ID 252530: 1-11.

9. Soudamani S, Malini T, Balasubramanian K. Effects of streptozotocin-diabetes and insulin replacement on the epididymis of prepubertal rats: histological and histomorphometric studies. Endocr Res. 2005; 31(2):81-98.

10. Mallidis C, Green BD, Rogers D, Agbaje IM, 
Hollis J, Migaud M et al. Metabolic profile changes in the testes of mice with streptozotocininduced type 1 diabetes mellitus. International $\mathrm{J}$ Androl 2009; 32(2):156-165.

11. Amaral S, Oliveira PJ, Ramalho-Santos J. Diabetes and the Impairment of Reproductive Function: Possible Role of Mitochondria and Reactive Oxygen Species. Curr Diabetes Rev 2008; 4(1):46-54.

12. Delfino M, Imbrogno N, Elia J, Capogreco F, Mazzilli F. Prevalence of diabetes mellitus in male partners of infertile couples. Minerva Urol Nefrol 2007; 59:131-135.

13. Portela JM, Tavares RS, Mota PC, RamalhoSantos J, Amaral S. High glucose concentrations per se do not adversely affect human sperm function in vitro. Reproduction $2015 ; 150(1)$ :7784.

14. Scarano WR, Messias AG, Oliva SU, Klinefelter GR, Kempinas WG. Sexual behaviour, sperm quantity and quality after short-term streptozotocin-induced hyperglycaemia in rats. Int J Androl 2006; 29(4):482-488.

15. Awad H, Salem A, Gadalla A, Abou El Wafa N, Mohamed OA. Erectile function in men with diabetes type 2: Correlation with glycemic control. Int J Impot Res. 2010; 22: 36-39.

16. Moore CR, Wang R. Pathophysiology and treatment of diabetic erectile dysfunction. Asian JAndrol 2006; 8(6): 675-684.

17. Hackett G, Cole N, Bhartia M, Kennedy D, Raju J, Wilkinson P. Testosterone replacement with long-acting testosterone undecanoate improves sexual function and quality-of-life parameters Vs. placebo in a population of men with type 2 diabetes. J Sex Med 2013; 10(6): 1612-1627.

18. Musicki B, Kramer MF, Becker RE, Burnett AL. Inactivation of phosphorylated endothelial nitric oxide synthase (Ser-1177) by O -GlcNAc in diabetes-associated erectile dysfunction. PNAS 2005; 102(33): 11870-11875.

19. Hirata H, Kawamoto K, Kikuno N, Kawakami T, Kawakami K, Saini S et al. Restoring erectile function by antioxidant therapy in diabetic rats. J Urol. 2009; 182(5): 2518-2525.

20. Zhou F, Li GY, Gao ZZ, Liu J, Liu T, Li W et al. The TGF- $\beta 1 / \mathrm{Smad} / \mathrm{CTGF}$ pathway and corpus cavernosum fibrous-muscular alterations in rats with streptozotocin-induced diabetes. J Androl 2012; 33(4): 651-659.

21. Pontes DA, Fernandes GSA, Piffer RC, Gerardin DCC, Pereira OCM, Kempinas WG. Ejaculatory dysfunction in streptozotocin-induced diabetic rats: the role of testosterone. Pharmacol Rep 2011; 63: 130-138.

22. Arafa M, El Tabie O. Medical treatment of retrograde ejaculation in diabetic patients: A hope for spontaneous pregnancy. J sex med 2008; 5(1): 194-198.

23. Sexton WJ, Jarow JP. Effect of Diabetes Mellitus upon Male Reproductive Function. Urology
1997; 49(4): 508-513.

24. Schoeller EL, Albanna G, Frolova AI, Moley $\mathrm{KH}$. Insulin rescues impaired spermatogenesis via the hypothalamic-pituitary-gonadal axis in Akita diabetic mice and restores male fertility. Diabetes 2012; 61(7): 1869-1878.

25. Tirabassi G, Corona G, Lamonica GR, Lenzi A, Maggi M, Balercia G. Diabetes MellitusAssociated Functional Hypercortisolism Impairs Sexual Function in Male Late-Onset Hypogonadism. Horm Metab Res 2015; 47: 9.

26. Nantia EA, Moundipa PF, Monsees TK, Carreau S. Medicinal plants as potential male antiinfertility agent: A review. Andrologia 2009; 19: $148-158$

27. Sangameswaran B, Jayakar B. Anti-diabetic, anti-hyperlipidemic and spermatogenic effects of Amaranthus spinosus Linn on streptozotocininduced diabetic rats. J Nat Med 2008; 62: 79-82.

28. Ghosh A, Jana K, Ali KM, De D, Chatterjee K, Ghosh D. Corrective role of Eugenia Jambolana on testicular impairment in streptozotocininduced diabetic male albino rats: An approach through genomic and proteomic study. Andrologia 2014; 46: 296-307.

29. Mallick C, Manda S1, Barik B, Bhattacharya A, Ghosh D. Protection of Testicular Dysfunctions by MTEC, a Formulated Herbal Drug, in Streptozotocin Induced Diabetic Rat. Biol Pharm Bull 2007; 30(1):84-90.

30. Khaki A, Fathiazad F, Nour M, Khaki AA, Maleki NA, Khamnei HJ, et al. Beneficial effects of Quercetin on sperm parameters in streptozotocin-induced diabetic rats. Phytother Res 2010; 24: 1285-1291.

31. Shalaby MA, Hamowich AR. Safety and efficacy of Zingiber officinale roots on fertility of male diabetic rats. Food Chem. Toxicol 2010; 48: 2920-2924.

32. Zhou F, Xin H, Liu T, Li G, Gao Z, Liu J et al. Effects of Icariside II on improving erectile function in rats with streptozotocin-induced diabetes. J Androl 2012; 33(5): 832-844.

33. Yang J, Wang T, Yang J, Rao K, Zhan Y, Chen R, et al. S-Allyl Cysteine restores erectile function through inhibition of reactive oxygen species generation in diabetic rats. Andrology 2013; 1 : 487-494

34. Yang R, Wang J, Chen Y, Sun Z, Wang R, Dai Y. Effect of Caffeine on erectile dysfunction via upregulating cavernous cyclic Guanosine monophosphate in diabetic rats. J Androl 2008; 29: $586-591$

35. Ha US, Koh JS, Kim HS, Woo JC, Kim SJ, Jang $\mathrm{H}$, et al. Cyanidin-3-O- $\beta$-D-glucopyranoside concentrated materials from mulberry fruit have a potency to protect erectile function by minimizing oxidative stress in a rat model of diabetic erectile dysfunction. Urol Int 2012; 88(4): 470-6.

36. Khaki A, Khaki AA, Hajhosseini L, Golzar FS, 
Ainehchi N. The anti-oxidant effects of Ginger and Cinnamon on spermatogenesis dys-function of diabetic rats. Afr J Tradit Complement Altern Med. 2014; 11(4): 1-8.

37. Thakur M, Chauhan NS, Sharma V, Dixit VK, Bhargava S. Effect of Curculigo orchioides on hyperglycemia-induced oligospermia and sexual dysfunction in male rats. Int J Impot Res. 2012; 24(1):31-7.

38. Nene UA, Coyaji K, Apte H. Infertility: A label of choice in the case of sexually dysfunctional couples. Patient Educ Couns 2005; 59: 234-238.

39. Penson DF, Latini DM, Lubeck DP, Wallace KL, Henning JM, Lue TF. Do impotent men with diabetes have more severe erectile dysfunction and worse quality of life than the general population of impotent patients?; Results from the exploratory comprehensive evaluation of erectile dysfunction (ExCEED) database. Diabetes care 2003; 26(4): 1093-99.

40. Oger-Roussel S, Behr-Roussel D, Caisey S, Kergoat M, Charon C, Audet A, et al. Bladder and erectile dysfunctions in the Type 2 diabetic Goto-Kakizaki rat. Am J Physiol Regul Integr Comp Physiol. 2013; 306: R108-R117. 
Table 1: Medicinal Plants used in treatment of male reproductive complications due to diabetes mellitus

\begin{tabular}{|c|c|c|c|c|c|c|c|}
\hline Medicinal plant & $\begin{array}{l}\text { Complication } \\
\text { treated }\end{array}$ & $\begin{array}{l}\text { Type of } \\
\text { study }\end{array}$ & $\begin{array}{l}\text { Route of } \\
\text { administration }\end{array}$ & $\begin{array}{l}\text { Daily Dose and Duration } \\
\text { of treatment }\end{array}$ & $\begin{array}{l}\text { Mechanism of } \\
\text { action }\end{array}$ & Outcome & References \\
\hline $\begin{array}{l}\text { Amaranthus } \\
\text { spinosus }\end{array}$ & Hypogonadism & $\begin{array}{l}\text { In vivo } \\
\text { (Rats) }\end{array}$ & Oral & $\begin{array}{l}250 \mathrm{mg} / \mathrm{kg} \\
500 \mathrm{mg} / \mathrm{kg} \\
(15 \text { days })\end{array}$ & $\uparrow$ Spermatogenesis & $\begin{array}{l}\uparrow \text { Testicular weight } \\
\uparrow \text { Sperm count }\end{array}$ & 27 \\
\hline Caffeine & $\begin{array}{l}\text { Erectile } \\
\text { dysfunction }\end{array}$ & $\begin{array}{l}\text { In vivo } \\
\text { (Rats) }\end{array}$ & Intragastric & $\begin{array}{l}10 \mathrm{mg} / \mathrm{kg} \\
20 \mathrm{mg} / \mathrm{kg} \\
(8 \text { weeks) }\end{array}$ & $\begin{array}{l}\uparrow \text { Cavernous cGMP } \\
\uparrow \text { ICP }\end{array}$ & $\begin{array}{l}\text { Improved erectile } \\
\text { function }\end{array}$ & 34 \\
\hline Dracaena arborea & $\begin{array}{l}\text { Testicular } \\
\text { dysfunction }\end{array}$ & $\begin{array}{l}\text { In vivo } \\
\text { (Rats) }\end{array}$ & Oral & $\begin{array}{l}100 \mathrm{mg} / \mathrm{kg} \\
500 \mathrm{mg} / \mathrm{kg} \\
\text { (3 weeks) }\end{array}$ & $\uparrow$ Antioxidation & $\begin{array}{l}\text { Restores testicular } \\
\text { morphology and } \\
\text { spermatogenesis }\end{array}$ & 7 \\
\hline $\begin{array}{l}\text { Eugenia } \\
\text { jambolana }\end{array}$ & $\begin{array}{l}\text { Testicular } \\
\text { dysfunction }\end{array}$ & $\begin{array}{l}\text { In vivo } \\
\text { (Rats) }\end{array}$ & Oral & $\begin{array}{l}20 \mathrm{mg} / 100 \mathrm{~g} \\
\text { (60 days) }\end{array}$ & $\uparrow$ Antioxidation & $\uparrow$ Organ weight & 28 \\
\hline \multirow[t]{2}{*}{ Zingiber officinale } & $\begin{array}{l}\text { Spermatogenesis } \\
\text { dysfunction }\end{array}$ & $\begin{array}{l}\text { In vivo } \\
\text { (Rats) }\end{array}$ & Oral & $\begin{array}{l}100 \mathrm{mg} / \mathrm{kg} \\
\text { (56days) }\end{array}$ & $\uparrow$ Antioxidation & $\begin{array}{l}\uparrow \text { Sperm parameters } \\
\text { and sex hormones }\end{array}$ & 31,36 \\
\hline & & & & $\begin{array}{l}100-300 \mathrm{mg} / \mathrm{kg} \\
(65 \text { days })\end{array}$ & & & \\
\hline Allium sativum & Testicular damage & $\begin{array}{l}\text { In vivo } \\
\text { (Rats) }\end{array}$ & Oral & $\begin{array}{l}1 \mathrm{ml} / 100 \mathrm{mg} \\
(3 \text { weeks }) \\
\text { (6 weeks) }\end{array}$ & $\uparrow$ Antioxidation & $\begin{array}{l}\text { Restores testicular } \\
\text { morphology and } \\
\text { serum testosterone }\end{array}$ & 6 \\
\hline Musa paradisiaca & $\begin{array}{l}\text { Testicular } \\
\text { dysfunction }\end{array}$ & $\begin{array}{l}\text { In vivo } \\
\text { (Rats) }\end{array}$ & Oral & $\begin{array}{l}\text { In MTEC } 60 \mathrm{mg} / 0.5 \mathrm{ml} \\
\text { olive oil/100 g twice daily } \\
\text { (15 days) }\end{array}$ & $\uparrow$ Antioxidation & $\begin{array}{l}\text { Improved organo- } \\
\text { somatic indices and } \\
\text { sperm parameters }\end{array}$ & 29 \\
\hline $\begin{array}{l}\text { Tamarindus } \\
\text { indica }\end{array}$ & $\begin{array}{l}\text { Testicular } \\
\text { dysfunction }\end{array}$ & $\begin{array}{l}\text { In vivo } \\
\text { (Rats) }\end{array}$ & Oral & $\begin{array}{l}\text { In MTEC } 60 \mathrm{mg} / 0.5 \mathrm{ml} \\
\text { olive oil } / 100 \mathrm{~g} \text { twice daily } \\
\text { (15 days) }\end{array}$ & $\uparrow$ Antioxidation & $\begin{array}{l}\text { Improved organo- } \\
\text { somatic indices \& } \\
\text { sperm parameters }\end{array}$ & 29 \\
\hline Coccinia indica & $\begin{array}{l}\text { Testicular } \\
\text { dysfunction }\end{array}$ & $\begin{array}{l}\text { In vivo } \\
\text { (Rats) }\end{array}$ & Oral & $\begin{array}{l}\text { In MTEC } 60 \mathrm{mg} / 0.5 \mathrm{ml} \\
\text { olive oil/100 g twice daily } \\
\text { (15 days) }\end{array}$ & $\uparrow$ Antioxidation & $\begin{array}{l}\text { Improved organo- } \\
\text { somatic indices \& } \\
\text { sperm parameters }\end{array}$ & 29 \\
\hline $\begin{array}{l}\text { Herba epimedii } \\
\text { (Icarisi } \\
\text { de II) }\end{array}$ & $\begin{array}{l}\text { Erectile } \\
\text { dysfunction }\end{array}$ & $\begin{array}{l}\text { In vivo } \\
\text { (Rats) }\end{array}$ & Oral & $\begin{array}{l}1,5 \text {, and } 10 \mathrm{mg} / \mathrm{kg} \\
(3 \text { months) }\end{array}$ & $\begin{array}{l}\uparrow \text { Expression of } \\
\text { eNOS, nNOS and } \\
\text { VEGF }\end{array}$ & $\begin{array}{l}\text { Improved erectile } \\
\text { function }\end{array}$ & 32 \\
\hline $\begin{array}{l}\text { Cinnamomum } \\
\text { zeylanicum }\end{array}$ & $\begin{array}{l}\text { Spermatogenesis } \\
\text { dysfunction }\end{array}$ & $\begin{array}{l}\text { In vivo } \\
\text { (Rats) }\end{array}$ & Oral & $\begin{array}{l}75 \mathrm{mg} / \mathrm{kg} \\
\text { (56 days) }\end{array}$ & $\uparrow$ Antioxidation & $\begin{array}{l}\text { Improved sperm } \\
\text { parameters and sex } \\
\text { hormones }\end{array}$ & 36 \\
\hline Quercetin & $\begin{array}{l}\text { Spermatogenesis } \\
\text { dysfunction }\end{array}$ & $\begin{array}{l}\text { In vivo } \\
\text { (Rats) }\end{array}$ & Intraperitoneal & $\begin{array}{l}15 \mathrm{mg} / \mathrm{kg} \\
\text { ( } 28 \text { days) }\end{array}$ & $\begin{array}{l}\uparrow \text { Antioxidation and } \\
\text { anti-inflammation }\end{array}$ & $\begin{array}{l}\text { Improved testicular } \\
\text { morphology and } \\
\text { sperm parameters }\end{array}$ & 30 \\
\hline $\begin{array}{l}\text { Scutellarin } \\
\text { (Erigeron } \\
\text { breviscapus) }\end{array}$ & Testicular damage & $\begin{array}{l}\text { In vivo } \\
\text { (Rats) }\end{array}$ & Oral & $\begin{array}{l}100 \mathrm{mg} / \mathrm{kg} \\
(2 \mathrm{months})\end{array}$ & $\begin{array}{l}\uparrow \text { Antioxidation and } \\
\text { improved } \\
\text { microcirculation }\end{array}$ & $\begin{array}{l}\text { Reduced apoptotic } \\
\text { and morphological } \\
\text { damage in the testes }\end{array}$ & 8 \\
\hline \multirow[t]{2}{*}{$\begin{array}{l}\text { Curculigo } \\
\text { orchioides }\end{array}$} & $\begin{array}{l}\text { Oligospermia and } \\
\text { sexual dysfunction }\end{array}$ & $\begin{array}{l}\text { In vivo } \\
\text { (Rats) }\end{array}$ & Oral & $\begin{array}{l}100 \mathrm{mg} / \mathrm{kg} \\
200 \mathrm{mg} / \mathrm{kg} \\
(28 \text { days })\end{array}$ & $\begin{array}{l}\uparrow \text { Antioxidation and } \\
\text { increased anabolic } \\
\text { activity }\end{array}$ & $\begin{array}{l}\text { Improved sexual } \\
\text { function and sperm } \\
\text { count }\end{array}$ & 37 \\
\hline & $\begin{array}{l}=\text { Endothelial nitric ox } \\
\mathrm{S}=\text { Nuclear nitric oxic } \\
=\text { Intracavernous press } \\
\mathrm{F}=\text { Vascular endothel } \\
\mathrm{C}=\text { Musa paradisiac } \\
\text { Increased } \\
\mathrm{P}=\text { Cyclic Guanosine- }\end{array}$ & $\begin{array}{l}\text { ide syntha } \\
\text { e synthase } \\
\text { ire. } \\
\text { al growth } \\
\text {, Tamarin } \\
\text { Monophos }\end{array}$ & $\begin{array}{l}\text { or. } \\
\text { idica, Eugenia }\end{array}$ & olana and Coccinia indica & & & \\
\hline
\end{tabular}




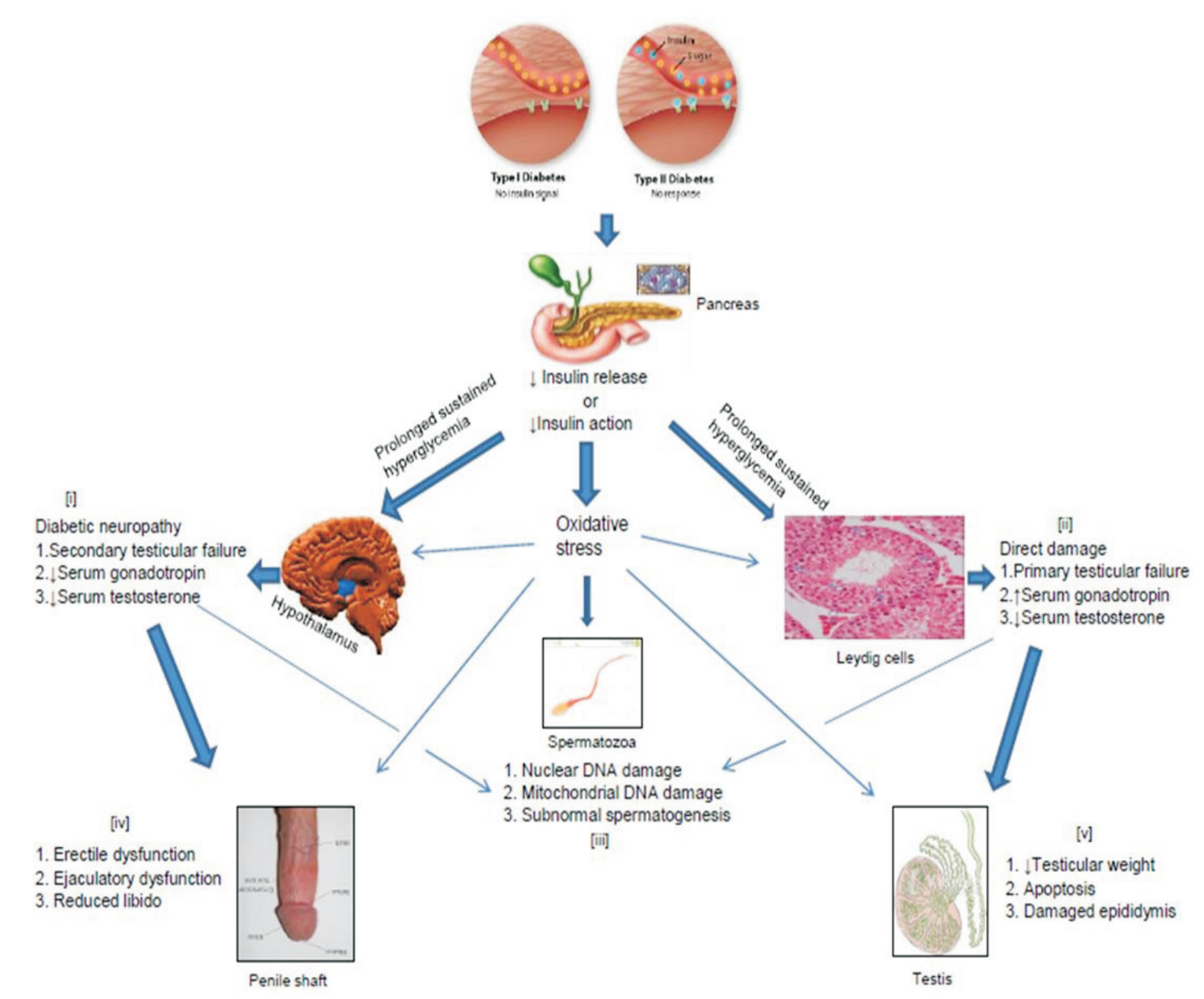

FIG. 1: The impact of diabetes mellitus on the male reproductive system 